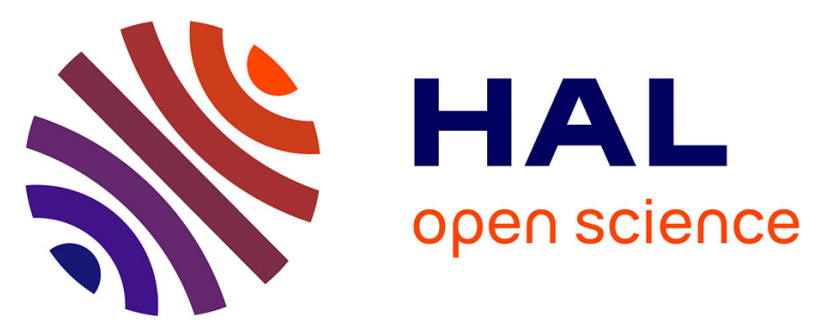

\title{
An original approach for lipophilic natural products extraction: Use of liquefied n-butane as alternative solvent to n-hexane
}

Vincent Rapinel, Natacha Rombaut, Njara Rakotomanomana, Alain Vallageas, Giancarlo Cravotto, Farid Chemat

\section{To cite this version:}

Vincent Rapinel, Natacha Rombaut, Njara Rakotomanomana, Alain Vallageas, Giancarlo Cravotto, et al.. An original approach for lipophilic natural products extraction: Use of liquefied n-butane as alternative solvent to n-hexane. LWT - Food Science and Technology, 2017, 85 (Part B), pp.524-533. 10.1016/j.lwt.2016.10.003 . hal-02621987

\section{HAL Id: hal-02621987 \\ https: / hal.inrae.fr/hal-02621987}

Submitted on 26 May 2020

HAL is a multi-disciplinary open access archive for the deposit and dissemination of scientific research documents, whether they are published or not. The documents may come from teaching and research institutions in France or abroad, or from public or private research centers.
L'archive ouverte pluridisciplinaire HAL, est destinée au dépôt et à la diffusion de documents scientifiques de niveau recherche, publiés ou non, émanant des établissements d'enseignement et de recherche français ou étrangers, des laboratoires publics ou privés. 


\title{
An original approach for lipophilic natural products extraction: Use of liquefied $n$-butane as alternative solvent to $n$-hexane
}

\author{
Vincent Rapinel a, b, c, Natacha Rombaut ${ }^{\text {b }}$, Njara Rakotomanomana ${ }^{\text {b, c }}$, Alain Vallageas a, \\ Giancarlo Cravotto ${ }^{\mathrm{d}}$, Farid Chemat ${ }^{\mathrm{b}, \mathrm{c},{ }^{*}}$ \\ a Celsius Sarl, 184 chemin du Bouray, 38200 Villette de Vienne, France \\ ${ }^{\mathrm{b}}$ Université d'Avignon et des Pays de Vaucluse, INRA, UMR408, GREEN Extraction Team, 84000 Avignon, France \\ ${ }^{c}$ Plateforme d'Eco-Extraction de Valréas (PEEV), 14 D ancienne route de Grillon, 84600 Valréas, France \\ ${ }^{\mathrm{d}}$ Dipartimento di Scienza e Tecnologia del Farmaco, Università di Torino, Via P. Giuria 9, 10125 Torino, Italy
}

Keywords:

Innovative apparatus

Substitution solvent

Food ingredients

Liquefied gas

\begin{abstract}
A B S T R A C T
Recent trends in food extraction techniques have largely focused on finding solutions that minimize the use of toxic solvents or to find alternatives for $n$-hexane. As an original solution, a new process for extraction of natural product using liquefied gases has been developed at laboratory scale. The applicability of this new process was demonstrated using $n$-butane as alternative solvent to $n$-hexane. Extraction of lipophilic natural products such as carrot oleoresin, caraway aromas and sunflower oil was assessed using liquefied $n$-butane. COSMO-RS simulations allowed determination of the relative solubility of the lipophilic compounds in liquefied $n$-butane and $n$-hexane. This theoretical approach was validated with extraction experiments on carrots, caraway seeds and sunflower seeds. Compositions of the extracts were comparable but the extract yields were lower using $n$-butane. For example the extraction yields were, with $n$-butane and with $n$-hexane respectively, $36.9 \%$ and $53.4 \%$ for sunflower seeds oil, $10.9 \%$ and $15.0 \%$ for caraway seed essential oil, $25.7 \%$ and $55.8 \%$ for carrots oleoresin. However the extracts obtained by using $n$-butane are directly free of solvents and also food grade, as it is an authorized solvent for foodstuff production.
\end{abstract}

\section{Introduction}

Among the pool of organic solvents, $n$-hexane is certainly the most well-established industrial solvent for extraction of lipophilic natural products such as aromas, carotenoids, and vegetable oils (Chemat-Djenni, Ferhat, Tomao, \& Chemat, 2010; Filly et al., 2014; Virot, Tomao, Ginies, \& Chemat, 2008). The wide use of $n$-hexane is due to its physico-chemical parameters e.g. low boiling point, low polarity, and chemical stability (Johnson \& Lusas, 1983). However, residual content in raw material, non-total recovery of hexane observed in industrial processes, growing environmental and health concerns are major constraints (Mikkelsen \& Miljøstyrelsen, 2014). Indeed, $n$-hexane is categorized as reprotoxic category 2 and as aquatic chronic toxic category 2 substance (Sicaire, Vian, Fine, Carre et al., 2015) and is ranked on the list of substances

* Corresponding author. Université d'Avignon et des Pays de Vaucluse, INRA, UMR408, GREEN Extraction Team, 84000 Avignon, France.

E-mail address: farid.chemat@univ-avignon.fr (F. Chemat). prohibited in cosmetic products (Regulation (EC) No 1223/2009 of the European Parliament).

Scientific community and industrials are challenged to identify alternative solvents to $n$-hexane. This trend has stimulated researches on alternative solvents, most of which are produced from renewable resources such as woods, cereals, seeds, oils, fats (Chemat \& Vian, 2014, pp. 205-219; Ishida \& Chapman, 2009). As examples, studies have been performed regarding the extraction of rapeseed oils using MeTHF (Sicaire, Vian, Fine, Carre et al., 2015; Sicaire, Vian, Fine, Joffre et al., 2015), caraway seeds aromas using $\alpha$-pinene (Filly, Fabiano-Tixier, Fernandez, \& Chemat, 2015) and extraction of rice bran oil using limonene (Mamidipally \& Liu, 2004). Such solvents have a good solvation power, are non-toxic and biodegradable (Chemat, 2011, p. 9). The main drawbacks of these solvents are their cost (MeTHF: $5 € / \mathrm{kg}$ (Sicaire, Vian, Fine, Carre et al., 2015; Sicaire, Vian, Fine, Joffre et al., 2015)), their relative high viscosity $\left(d\right.$-limonene $=9.0 \times 10^{-4} \mathrm{~Pa} \mathrm{~s}$ at $25^{\circ} \mathrm{C} ; \alpha$ pinene $=1.3 \times 10^{-3} \mathrm{~Pa} \mathrm{~s}$ at $25^{\circ} \mathrm{C}$ (Clará, Marigliano, \& Sólimo, 2009)), their high boiling point (d-limonene $=175.5{ }^{\circ} \mathrm{C}$ at 
Version définitive du manuscrit publiée dans / Final version of the manuscript published in :

LWT - Food Science and Technology (2016), 10 p., DOI: 10.1016/lwt.2016.10.003

Journal homepage : http://www.elsevier.com/locate/lwt

101.3 kPa (Chemat-Djenni et al., 2010); $\alpha$-pinene $=158{ }^{\circ} \mathrm{C}$ at $101.3 \mathrm{kPa}$ (Filly et al., 2015)) and the possible generation of offflavors (Filly et al., 2015).

In the last decades, research for new solvents has revived the interest for the use of liquefied gases as extraction solvents. Many studies have been performed on natural product extraction using supercritical $\mathrm{CO}_{2}$, but the high working pressure (7.5-45 MPa) has limited the industrial applications (Baysal, Ersus, \& Starmans, 2000; Ben Rahal, Barba, Barth, \& Chevalot, 2015; Coelho et al., 2012; Couto et al., 2010; Hubert \& Vitzthum, 1978; Koubaa et al., 2015; Koubaa et al., 2016; Xu et al., 2011). More recently, some studies have been focused on extraction processes involving liquefied gases at lower pressure (200-1000 kPa), such as n-propane (da Silva et al., 2015; Sekhon, Maness, \& Jones, 2015; Zanqui et al., 2015), n-butane (Novello et al., 2015; Yang, Teo, \& Xu, 2004), dimethyl ether (Kanda \& Li, 2011; Kanda \& Makino, 2009; Oshita et al., 2015), tetrafluoropropene (Suberu, Yamin, Cornell, Sam, \& Lapkin, 2016), tetrafluoroethane (Lapkin, Plucinski, \& Cutler, 2006; Mustapa, Manan, Mohd Azizi, Nik Norulaini, \& Omar, 2009), eventually with co-solvents (Jesus et al., 2013; Pessoa et al., 2015). All these studies describe a dynamic process with continuous solvent recirculation using pumps and/or compressors which are prone to cavitation issues (Brennen, 1995; Franc \& Michel, 2005). Alternatively, a new process has been recently proposed (Fig. 1) which does not require the use of pumps and compressors. The unit designed has the specificity to rely on gravity for the liquefied gases circulation in the equipment. Consecutively, energy consumption is reduced compared to other liquefied gases processes using pumps and compressors. Extraction is enabled by liquefied gas contacting with a raw material inside an extractor during a set time. Then the mixture of liquefied solvent and extract is separated in an evaporator, allowing the liquefied gas to turn in a gaseous state. Therefore, no traces of the solvent remain in the extract.

In this paper, the applicability of this newly developed process has been investigated using $n$-butane for extraction of lipophilic compounds such as oleoresin, essential oil and vegetable oil. The choice of $n$-butane as alternative solvent to $n$-hexane was motivated by its close chemical structure, its gentle vapor pressure, its low price and its classification as authorized solvent for foodstuff production without limitation (Directive 2009/32/EC).

The potential of liquefied $n$-butane for extraction of lipophilic compounds will be compared to the conventional solvent $n$-hexane through two approaches: a theoretical approach with a predictive computational model, COSMO-RS (COnductor like Screening MOdel for Real Solvents), coupled with lab-scale trials. Three plant material traditionally extracted with $n$-hexane were chosen for the comparative study: carrots (Daucus carota L.) for the extraction of high-value products i.e. carotenoids, caraway seeds (Carum carvi L.) for the extraction of volatile aromatic compounds and sunflower seeds (Helianthus annuus L.) for the extraction of fats and oils. The extracts will be analyzed quantitatively (extraction yield) and qualitatively (GC, HPLC) in order to compare the efficiency of $n$ butane versus $n$-hexane for the extraction of lipophilic natural products.

\section{Materials and methods}

\subsection{Chemicals}

For extraction, $n$-hexane analytical grade (VWR International, Radnor, USA) and $n$-butane, 95\% purity without mercaptan (Inventec Performance Chemical, St Priest, France) were used in this study.
(A)

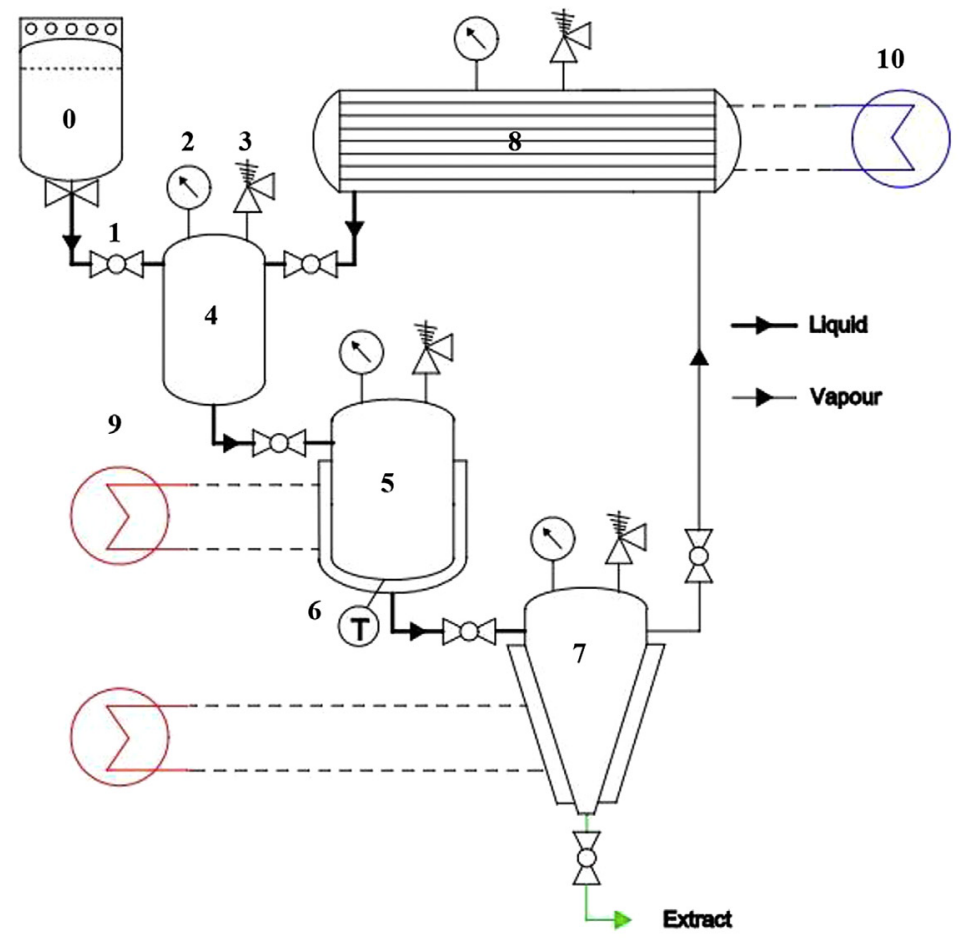

(B)

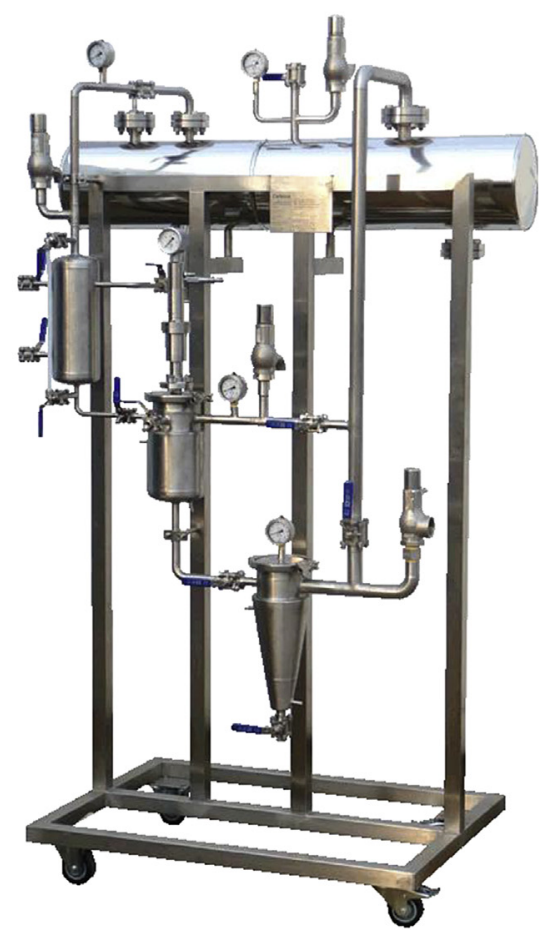

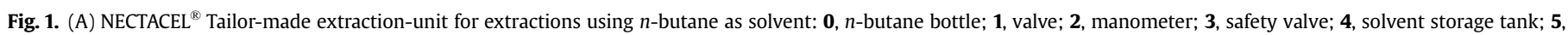

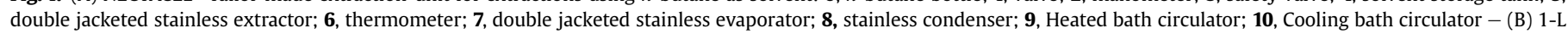
extraction unit manufactured by Celsius Sarl (Villette de Vienne, France). 
Version définitive du manuscrit publiée dans / Final version of the manuscript published in :

LWT - Food Science and Technology (2016), 10 p., DOI: 10.1016/lwt.2016.10.003

Journal homepage : http://www.elsevier,com/locate/lwt

For analytical procedures, all reagents were HPLC grades. Acetonitrile, methanol, ammonium acetate, dichloromethane, chloroform, acetone, tert-butyl methyl ether (TBME) and trimethylsulfonium hydroxide (TMSH) were purchased from SigmaAldrich (St. Louis, USA).

$\beta$-carotene (>98\% UV purity) was purchased from Extrasynthèse (Genay, France). Fatty Acids Methyl Esters mix (Supelco 37 FAME mix), pentadecanoic acid (C15:0, 99\% purity), $d$-carvone (98\% purity) and $d$-limonene (99\% purity) were purchased from SigmaAldrich (St. Louis, USA).

\subsection{Plant materials}

Dried carrots and sunflower seeds were purchased in 2015 from Herbier du Diois (Châtillon-en-Diois, France). Caraway seed powder was purchased from Lîle aux épices (Port-Vendres, France). The plant materials were prepared following the same procedures for both $n$-butane and $n$-hexane extractions. Dried carrot cubes and sunflower seeds were ground into a fine powder using a grinder (Kinematica AG Microtron MB 550, Luzern, Switzerland; grinding duration $=15 \mathrm{~s}$ ) just before extraction. Caraway seed powder was used directly as is.

\subsection{Liquefied gases apparatus and extraction procedure}

Extractions were performed on a $1 \mathrm{~L}$ pilot plant presented in Fig. 1 (NECTACEL ${ }^{\circledR}$, Celsius sarl, Villette de Vienne, France). The unit designed has the specificity to rely on gravity for the liquefied gases circulation in the equipment in an isobaric mode. After extraction, the liquefied gas is evaporated in an evaporator, where the liquefied gas turns into gas. Vapors are condensed in a condenser (cooling temperature $=0{ }^{\circ} \mathrm{C}$ ) and stored in a storage tank which further supplies liquefied gases for extraction. This way about $95 \%$ of gas is recycled in $10 \mathrm{~min}$.

Using liquefied gases as solvent for solid-liquid extractions requires an equipment resistant to the vapor pressure generated at room temperature (200-400 kPa). The unit comprises 4 stainless steel vessels (Fig. 1): a solvent storage tank (4), a double-jacketed stainless steel extractor of $1.5 \mathrm{~L}$ (5), a double-jacketed stainless steel evaporator (7) and a stainless steel condenser (8). Each vessel is equipped with a manometer (2) and a safety valve (3) and was manufactured in compliance with the PED Directive (Pressure Equipment Directive 97/23/CE) and ATEX Directive (EXplosive ATmosphere, Directive 2014/34/UE).

Liquefied $n$-butane extractions were performed using the following general procedure (Fig. 2). First, $75 \mathrm{~g}$ of ground material is introduced in a filtering sock (porosity $50 \mu \mathrm{m}$ ) placed inside the extractor (5) then the all device is placed under vacuum to remove oxygen. Next, the liquid $n$-butane is transferred from its bottle (0) to the storage tank (4). About $1.5 \mathrm{~L}$ of liquid $n$-butane is introduced into the extractor at room temperature under pressure $\left(20^{\circ} \mathrm{C}\right.$ at $200 \mathrm{kPa}$ ). The solvent is then flowed by gravity to the extractor (5). The extractor is heated at the set temperature $\left(20,30\right.$ or $\left.40^{\circ} \mathrm{C}\right)$ via the double jacket during $2 \mathrm{~h}$.

After $2 \mathrm{~h}$ of solid/liquid contacting, the solvent containing the extract is transferred to the evaporator (7) where the solvent is

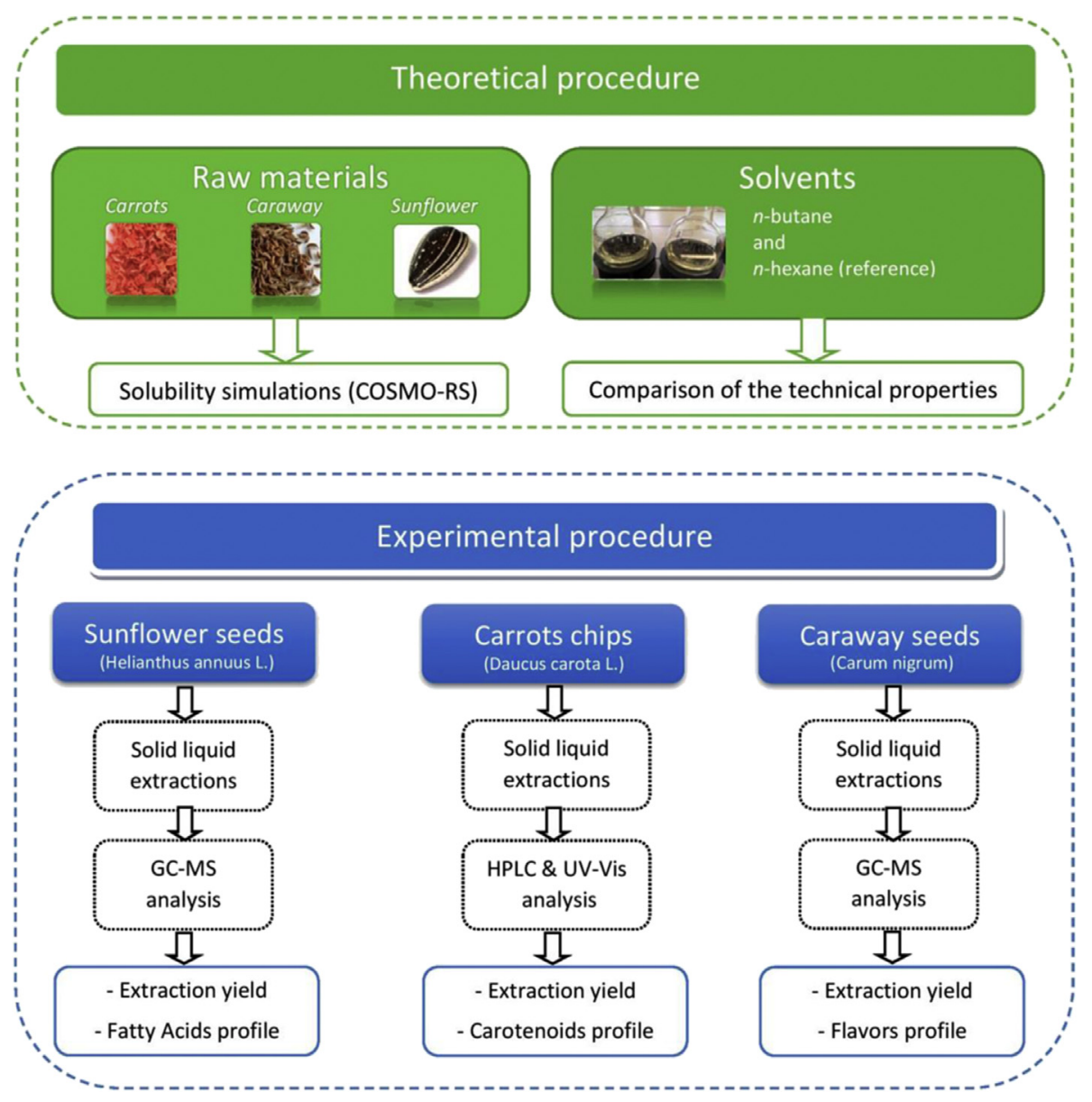

Fig. 2. Experimental procedure. 
evaporated. The vapors of solvent go up to the condenser (8) for recycling while the extract remains at the bottom of the evaporator. The remaining extract is collected in a flask, solubilized in $100 \mathrm{~mL}$ of $n$-hexane for analysis purpose and stored at $4{ }^{\circ} \mathrm{C}$ prior to analysis. Each extraction was made in triplicate.

\subsection{Reference: $n$-hexane extraction}

Reflux extraction using $n$-hexane was used as reference extraction procedure. $10 \mathrm{~g}$ of raw material are weighed and placed in a flask containing $100 \mathrm{~mL}$ of $n$-hexane. The mixture was heated at hexane boiling point $\left(68^{\circ} \mathrm{C}\right)$ during $2 \mathrm{~h}$. After cooling at ambient temperature, the mixture was filtered $(1.6 \mu \mathrm{m})$ to separate solid residues and then $n$-hexane was evaporated using a rotary vacuum evaporator $\left(40{ }^{\circ} \mathrm{C} ; 15 \mathrm{kPa}\right)$. Extract was stored at $4{ }^{\circ} \mathrm{C}$ prior to analysis. Each extraction was made in triplicate.

\subsection{Extract analysis}

\subsubsection{Analysis of carotenoids by high performance liquid} chromatography

The protocol was adapted from (Yara-Varon et al., 2016). Identification of carotenoids in carrot oleoresin was performed by high performance liquid chromatography (Agilent 1100) equipped with a UV-Vis detector (Diode Array Detector) under the following conditions: Eluent, acetonitrile/methanol (with $0.6 \mathrm{~g} / 100 \mathrm{~g}$ of ammonium acetate)/dichloromethane (ratio: $77 / 20 / 3, \mathrm{~mL} / \mathrm{mL} / \mathrm{mL}$ ) in an isocratic mode; Injection volume, $10 \mu \mathrm{L}$; column, $\mathrm{C} 18$ column $(150 \times 3 \mathrm{~mm}-3 \mu \mathrm{m}$ - flow rate $=1.4 \mathrm{~mL} / \mathrm{min})$; temperature, $25^{\circ} \mathrm{C}$; detector, diode array detector set at $464 \mathrm{~nm}$. Carrot oleoresin was diluted in chloroform prior to injection. Quantification was made using external calibration with a $\beta$-carotene standard (UV purity $>98 \%$ ). Results are expressed in grams per $100 \mathrm{~g}$ of oleoresin sample.

\subsubsection{Ultra Violet (UV) spectroscopy determination of total} carotenoid content

The protocol is adapted from (Yara-Varon et al., 2016). The carotenoid content in the extracts was measured spectrophotometrically (Biochrom Libra S22 UV/Vis Spectrophotometer, Cambridge, England) in a $1 \mathrm{~cm}$ optical path-length quartz cell at $450 \mathrm{~nm}$ for $\beta$-carotene in each extract against the $n$-hexane used as a blank. The following equation was used to calculate the carotenoid concentration, C ( $\mathrm{mg} \mathrm{L}^{-1}$ ) (Strati \& Oreopoulou, 2011):

$C=\frac{A_{\lambda \max } \times 10^{4}}{A_{1 \% \mathrm{~cm}}^{1 \%}}$

where $A_{\lambda \max }$ is the absorbance of the extract at $\lambda_{\max }$ and $A_{1 \mathrm{~cm}}^{1 \%}$ is the absorption coefficient (absorbance at a given wavelength of a $1 \mathrm{~g} /$ $100 \mathrm{~g}$ solution in a spectrophotometer cuvette with a $1 \mathrm{~cm}$ light path) of $\beta$-carotene in the respective solvent. The absorption coefficient was 2592 in $n$-hexane at $450 \mathrm{~nm}$. Finally the yield of carotenoids in each extract was calculated and expressed as $\mathrm{mg}$ ( $\beta$ carotene) $100 \mathrm{~g}^{-1}$ of dry matter.

\subsubsection{Gas chromatography analysis of aromatic compounds}

The detection of carvone and limonene in caraway essential oil was performed by gas chromatography (GC 7890, Agilent Technologies, Santa Clara, USA) equipped with a FID and quadrupole detector under the following conditions: vector gas, Helium $(1.1 \mathrm{~mL} / \mathrm{min})$; injector temperature, $250{ }^{\circ} \mathrm{C}$; injected volume, $1 \mu \mathrm{L}$; split, 1:100; column, VF-MAX type ( $30 \mathrm{~m} \times 0.25 \mathrm{~mm}$, film thickness x $0.25 \mu \mathrm{m}$, Agilent J\&W Scientific, Folsom, USA); temperature gradient, $60{ }^{\circ} \mathrm{C}$ for $1 \mathrm{~min}$, increased at $240{ }^{\circ} \mathrm{C}$ (rate: $3^{\circ} \mathrm{C} / \mathrm{min}$ ) and held for $5 \mathrm{~min}$. The detection is done by the FID at $250^{\circ} \mathrm{C}$. Carvi oleoresins are diluted in acetone prior to injection. For identified compounds, quantification is made with MS detector. Quadrupole is set at $150{ }^{\circ} \mathrm{C}$ with a source and transfer line at $230{ }^{\circ} \mathrm{C}$. Helium flow rate is kept at $1.1 \mathrm{~mL} / \mathrm{min}$. Quantification of carvone and limonene is performed using external calibration with corresponding standards. Results are expressed in mass ratio carvone/ limonene.

\subsubsection{Gas chromatography analysis of fatty acids}

Identification and quantification of fatty acids in sunflower oil was performed by gas chromatography (GC 3800 VARIAN Agilent Technologies, Santa Clara, USA) equipped with a FID detector under the following operating conditions: vector gas, Helium (207 kPa); injected volume, $1 \mu \mathrm{L}$; split, 1:50; column, DB32 type $(60 \mathrm{~m} \times 0.25 \mathrm{~mm}$; film thickness x $0.25 \mu \mathrm{m}$, Agilent J\&W Scientific, Folsom, USA); oven temperature, $120{ }^{\circ} \mathrm{C}$; temperature program: $120{ }^{\circ} \mathrm{C}$ for $5 \mathrm{~min}$, increased at $200{ }^{\circ} \mathrm{C}$ (rate: $5^{\circ} \mathrm{C} / \mathrm{min}$ ) and held for $10 \mathrm{~min}$, increased at $230^{\circ} \mathrm{C}$ (rate: $2^{\circ} \mathrm{C} / \mathrm{min}$ ) and held during $15 \mathrm{~min}$.

Fatty Acid Methyl Esters were obtained according to the following procedure: triglycerides were diluted in TBME (100 mg of oil into $10 \mathrm{~mL}$ of TBME). To $200 \mu \mathrm{L}$ of this mixture were added $100 \mu \mathrm{L}$ of TMSH for transesterification and derivatization of fatty acids. Detection of eluted fatty acids methyl esters (FAMEs) is done by FID at $300^{\circ} \mathrm{C}$. Eluted FAMEs are identified by their retention time in comparison with a standard mix (Supelco 37 FAME mix, SigmaAldrich, USA). Quantification is performed by internal standard calibration (C15:0). Results are expressed in grams of a given fatty acid in $100 \mathrm{~g}$ of the sunflower oil sample.

\subsection{Statistical treatment}

The extraction yields were calculated according to the following equation:

$$
\text { Yield }(\%)=\frac{\text { massofextract }(g)}{\text { massofinitialplantmaterial }(g)} \times 100
$$

The repeatability of the results was expressed as standard deviation values (for caraway seeds and carrots) or pooled standard deviation values (for sunflower seeds). The pooled standard deviation (pooled SD) values were calculated as the square root of the sum of individual variances pondered by the individual degrees of freedom of each series of replicates (Box, Hunter, \& Hunter, 1978).

\subsection{Computational method: COSMO-RS calculations}

The Conductor-like Screening Model for Real Solvents (COSMORS) is a calculation method developed by (Klamt, 2003). This approach combines quantum chemical with thermodynamical statistics for the determination and prediction of the chemical potential of a molecule in a liquid without any experimental data. Thus, COSMO-RS can be used as a decision-making tool for solvent screening (Filly et al., 2015; Sicaire, Vian, Fine, Carre et al., 2015; Sicaire, Vian, Fine, Joffre et al., 2015; Suberu et al., 2016).

COSMO-RS procedure comprised a first step at microscopic scale followed by a macroscopic step. Firstly the COSMO model is used to apply a virtual conductor environment for the molecule. In this environment the molecule induced a polarization charge density on its surface depicted on the $\sigma$-surface (see Fig. 3). During the quantum calculation self-consistency algorithm, the solute molecule is converged to its energetically optimal state in the conductor with respect to its electron density and geometry.

Based on the obtained polarization charge density the second 


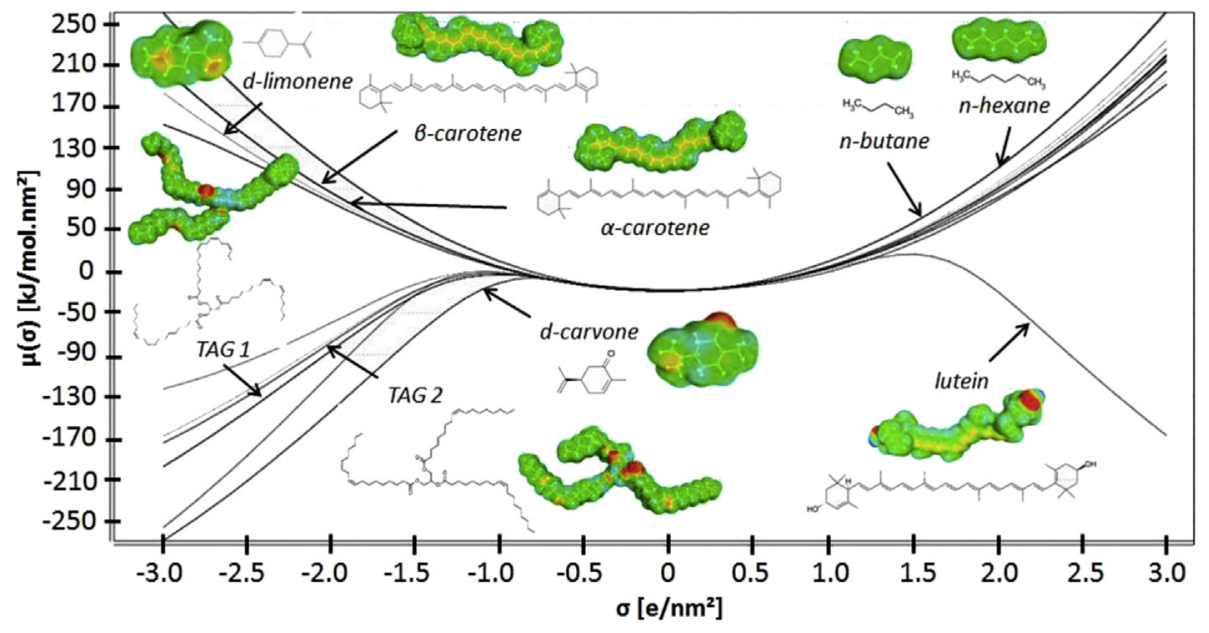

Fig. 3. $\sigma$-potentials of solutes and solvents calculated using COSMO-RS model.

step used a statistical thermodynamic calculation to quantify the solute interaction energy. The spatial distribution of the polarization charge $\sigma$ of the molecule was then converted into a surface composition function ( $\sigma$-profile). This $\sigma$-profile (see Fig. 4 ) provides information about the molecular polarity distribution. The thermodynamics of the molecular interactions was used to calculate the chemical potential of the surface segment ( $\sigma$-potential) using COSMOthermX program (version C30 release 14.10). The $\sigma$-potential (see Fig. 3) can be interpreted as the affinity between a solvent $S$ and the surface $\sigma$ via electrostatic interactions and hydrogen bonds. The part of the negative charge of the molecule was located on the right side (acceptor hydrogen bonds) with positive $\sigma$ values while the part of the positive charges was located on the left side (donor hydrogen bonds) with negative $\sigma$-values. Generally, the region $\sigma \pm$ $1 \mathrm{e} / \mathrm{nm}^{2}$ was considered to be non-polar or weakly polar. The $\sigma$ profile and the $\sigma$-potential were used to interpret the affinity of the solvent for surface polarity, to understand the interaction between the compound and a list of solvents and finally, to estimate the thermodynamic properties of the system.

In addition, the software COSMOthermX allows calculation of the affinity between a solute and the solvent in terms of logarithm of the solubility in mole fractions ( $\log 10$ (x_solub)).

The logarithm of the best solubility (i.e. solute and solvent are miscible) is equal to 0 and all other solvents were given relative to the best solvent(s). Also, the logarithm was transformed into probability of solubility and was expressed in percentage. The calculations for solutes and solvents were performed at $25^{\circ} \mathrm{C}$.

\section{8. n-butane as alternative solvent to n-hexane: properties comparison}

In order to determine if $n$-butane can be an alternative to $n$ hexane, in a first part a comparison of technical properties was made. In a second part, the solubility of target lipophilic compounds in both $n$-butane and $n$-hexane was assessed by COSMO-RS simulation.

Table 1 reports physicochemical properties of $n$-butane and $n$ hexane. Data was obtained from ACD-labs and from Air Liquide gas encyclopedia. The energy of evaporation for $1 \mathrm{~kg}$ of solvent at $25^{\circ} \mathrm{C}$ was calculated using the specific heat, the latent heat of

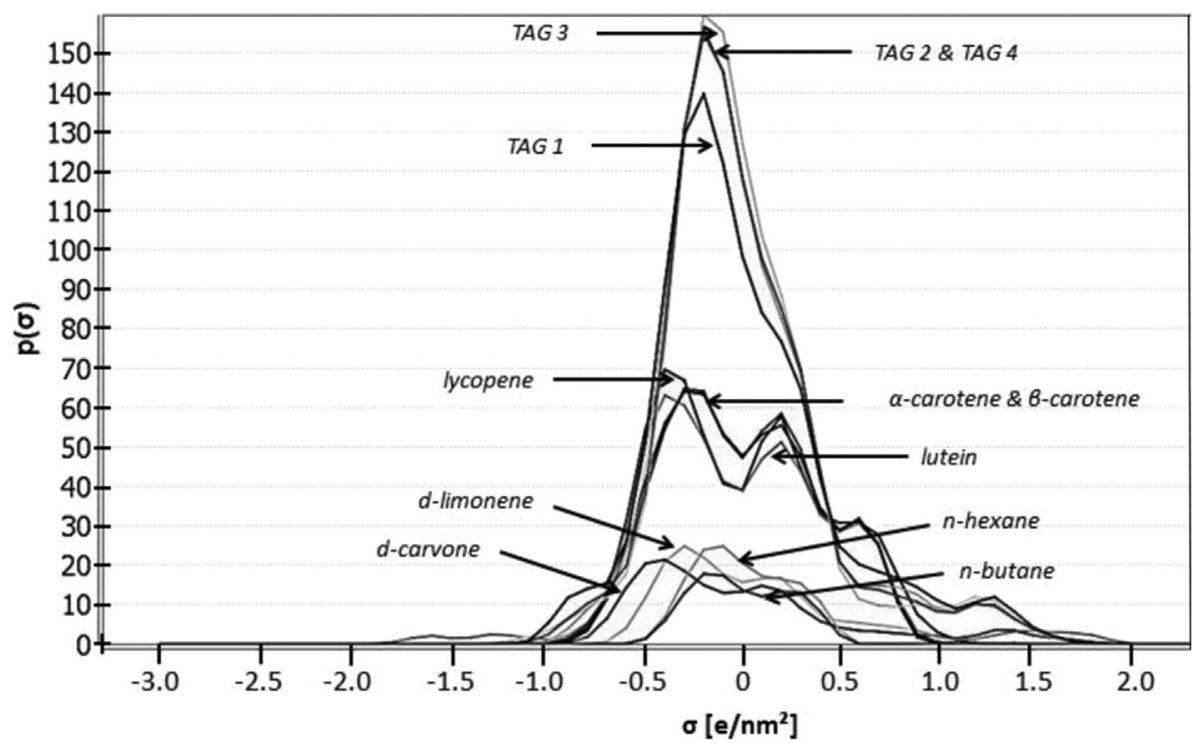

Fig. 4. $\sigma$-potentials of solutes and solvents calculated using COSMO-RS model. 
Version définitive du manuscrit publiée dans / Final version of the manuscript published in :

LWT - Food Science and Technology (2016), 10 p., DOI: 10.1016/lwt.2016.10.003

Journal homepage : http://www.elsevier.com/locate/lwt

Table 1

Comparison of technical properties of $n$-hexane and $n$-butane (Source: ACD-Labs).

\begin{tabular}{|c|c|c|c|}
\hline Properties & Unit & n-hexane & $n$-butane \\
\hline Molecular weight & {$[\mathrm{g} / \mathrm{mol}]$} & 86.2 & 58.1 \\
\hline Density $\left(25^{\circ} \mathrm{C}\right)$ & {$\left[\mathrm{kg} / \mathrm{m}^{3}\right]$} & 0.65 & 0.57 \\
\hline Viscosity $\left(25^{\circ} \mathrm{C}\right)$ & [Pa.s] & $3.210^{-4}$ & $1.610^{-4}$ \\
\hline Boiling Point (101.3 kPa) & {$\left[{ }^{\circ} \mathrm{C}\right]$} & 68.5 & -0.5 \\
\hline Latent heat of vaporization & {$[\mathrm{kJ} / \mathrm{kg}]$} & 334 & 386 \\
\hline Specific heat & {$\left[\mathrm{kJ} / \mathrm{kg} \cdot{ }^{\circ} \mathrm{C}\right]$} & 2.23 & 2.4 \\
\hline Evaporation energy per $\mathrm{kg}$ of solvent $(101.3 \mathrm{kPa})$ & [kW.h] & 0.12 & 0.11 \\
\hline Equivalent $\mathrm{CO}_{2}\left(1 \mathrm{~kW} \mathrm{~h}=800 \mathrm{~g}\right.$ of $\left.\mathrm{CO}_{2}\right)$ & {$[\mathrm{g}]$} & 96 & 88 \\
\hline Solubility in water $\left(25^{\circ} \mathrm{C}\right)$ & {$\left[\mathrm{kg} / \mathrm{m}^{3}\right]$} & 0.05 & 0.06 \\
\hline $\log 10 \mathrm{P}$ & & 3.9 & 2.9 \\
\hline Flash point & {$\left[{ }^{\circ} \mathrm{C}\right]$} & -23 & -60 \\
\hline Auto-ignition temperature & {$\left[{ }^{\circ} \mathrm{C}\right]$} & 225 & 287 \\
\hline Resource & & Petroleum & Petroleum \\
\hline Toxic & & Yes & No \\
\hline $\mathrm{CMR}^{\mathrm{a}}$ classification & & 2 & 1 \\
\hline
\end{tabular}

a Carcinogenic, Mutagenic and or toxic to Reproduction.

vaporization and the boiling point.

Both $n$-butane and $n$-hexane have a similar lipophilic behavior, with close solubility in water $\left(0.05 \mathrm{~kg} / \mathrm{m}^{3}\right.$ and $0.06 \mathrm{~kg} / \mathrm{m}^{3}$ at $\left.25^{\circ} \mathrm{C}\right)$, $\log 10 \mathrm{P}$ value (2.9 and 3.9$)$ and density $\left(0.57\right.$ and $\left.0.65 \mathrm{~kg} / \mathrm{m}^{3}\right)$. The comparison of boiling points (bp) and flash points (fp) shows that $n$-butane is logically much more volatile than $n$-hexane (bp $=-0.5^{\circ} \mathrm{C}, \mathrm{fp}=-60{ }^{\circ} \mathrm{C}$ and $\mathrm{bp}=68.5^{\circ} \mathrm{C}, \mathrm{fp}=-23^{\circ} \mathrm{C}$ respectively). $n$-butane also has a lower viscosity $\left(1.6 \times 10^{-4}\right.$ Pa $s$ vs. $3.2 \times 10^{-4} \mathrm{~Pa} \mathrm{~s}$ ). Comparison of evaporation energies shows that $n-$ butane has a slightly better score than $n$-hexane, with $0.11 \mathrm{kWh}$ and $0.12 \mathrm{kWh}$ respectively (source: ACD labs). This small difference has a direct impact on the energy consumption regarding the equivalent $\mathrm{CO}_{2}$ with respectively $88 \mathrm{~g}_{\mathrm{CO} 2}$ and $96 \mathrm{~g}_{\mathrm{CO} 2}$. These calculations have been made according to the literature: to obtain $1 \mathrm{kWh}$ from coal or fuel, $800 \mathrm{~g}$ of $\mathrm{CO}_{2}$ will be emitted during combustion of fossil fuel (Farhat et al., 2011).

In conclusion, the two solvents have very close technical properties and due to safety and energetic considerations, $n$-butane could be an alternative to $n$-hexane as extraction solvent.

\section{Results and discussion}

3.1. Evaluation of target compound solubility in n-butane and in hexane

A COSMO-RS simulation was performed to determine the relative solubility in $n$-hexane and $n$-butane of several components from caraway seeds (carvone, limonene), from sunflower seeds (triacylglycerols (TAGs): TAG1 (R1: C18:3n-3, R2: C18:2n-6, R3: C18:2n-6); TAG2 (R1: C18:1n-9, R2: C18:1n-9, R3: C18:2n-6); TAG3 (R1: C18:1n-9, R2: C18:1n-9, R3: C18:1n-9); TAG4 (R1: C18:1n-9, R2: C18:2n-6, R3: C18:2n-6)) and from carrots ( $\alpha$-carotene, $\beta$ carotene, lutein, lycopene).

Table 2 reports the solubility results, expressed in probability of solubilization (\%). As a reminder the simulations were performed at room temperature $\left(25^{\circ} \mathrm{C}\right)$ considering that both solutes and solvents were in a liquid state. According to the rule "like dissolve like", $n$-butane and n-hexane, respectively a C4 and C6 n-alkane, should have nearly the same solubilization power towards each molecule. As expected, $n$-hexane and $n$-butane showed a high probability of solubilization $(80-100 \%$, i.e. $\log 10$ (x_solub) $>-0.1$ ) for apolar solutes like carotenes, TAGs and limonene. Similarly, both solvents showed a low probability of solubility $(0-30 \%$, i.e. $\log 10\left(\mathrm{x} \_\right.$solub $)<-0.5$ ) for more polar solutes such as carvone and lutein. It can be concluded that the COSMO-RS simulation suggests that $n$-butane is a good potential candidate for the substitution of $n$-hexane, with a very close polarity and an almost identical probability of solubilization.

\subsection{Experimental study}

Liquefied gas extraction using this new process is new to literature. In this section, the extraction performances of liquefied $n$ butane were compared to $n$-hexane for carotenoids from carrots,

Table 2

COSMO-RS: relative solubility $(\log 10$ (x_solub)) and probability of solubility of solutes in $n$-hexane and $n$ butane at $25^{\circ} \mathrm{C}$. Dark grey: high probability of solubility (60-100\%); grey: medium probability (20-60\%); light grey: low probability $(0-20 \%)$.

\begin{tabular}{|c|c|c|c|c|c|}
\hline \multirow[b]{2}{*}{ Matrix } & \multirow[b]{2}{*}{ Solute } & \multicolumn{2}{|c|}{$n$-hexane } & \multicolumn{2}{|c|}{$n$-butane } \\
\hline & & $\log 10(x$ _solub $)$ & $\begin{array}{c}\text { Probability } \\
(\%)\end{array}$ & $\log 10(x$ _solub $)$ & $\begin{array}{c}\text { Probability } \\
(\%)\end{array}$ \\
\hline \multirow{4}{*}{$\begin{array}{l}\text { Sunflower } \\
\text { seed }\end{array}$} & TAG 1 & -0.64 & $23.0 \%$ & -0.10 & $78.5 \%$ \\
\hline & TAG 2 & 0 & $100.0 \%$ & 0 & $100.0 \%$ \\
\hline & TAG 3 & 0 & $100.0 \%$ & 0 & $100.0 \%$ \\
\hline & TAG 4 & 0 & $100.0 \%$ & 0 & $100.0 \%$ \\
\hline \multirow{2}{*}{$\begin{array}{c}\text { Caraway } \\
\text { seed }\end{array}$} & Carvone & -0.61 & $24.5 \%$ & -0.57 & $26.9 \%$ \\
\hline & Limonene & -0.08 & $83.8 \%$ & -0.03 & $93.1 \%$ \\
\hline \multirow{4}{*}{ Carrots } & $\alpha$-carotene & -0.03 & $93.7 \%$ & 0 & $100.0 \%$ \\
\hline & $\beta$-carotene & -0.04 & $91.3 \%$ & 0 & $100.0 \%$ \\
\hline & Luteine & -2.30 & $0.5 \%$ & -1.96 & $1.1 \%$ \\
\hline & Lycopene & -0.27 & $53.8 \%$ & 0 & $100.0 \%$ \\
\hline
\end{tabular}


Version définitive du manuscrit publiée dans / Final version of the manuscript published in :

LWT - Food Science and Technology (2016), 10 p., DOI: 10.1016/lwt.2016.10.003

Journal homepage : http://www.elsevier.com/locate/lwt

Table 3

Extraction yield and fatty acid composition of sunflower oil extracted with $n$-hexane and $n$-butane. Number of replicates $=3$.

\begin{tabular}{|c|c|c|c|c|c|}
\hline \multirow{3}{*}{ Fatty acids } & \multirow{3}{*}{$\begin{array}{r}\text { Pressure } \\
\text { Temperature }\end{array}$} & \multicolumn{3}{|c|}{$n$-butane } & \multirow{2}{*}{$\frac{n \text {-hexane }}{\text { atm. }}$} \\
\hline & & $200 \mathrm{kPa}$ & $280 \mathrm{kPa}$ & $370 \mathrm{kPa}$ & \\
\hline & & $20^{\circ} \mathrm{C}$ & $30^{\circ} \mathrm{C}$ & $40^{\circ} \mathrm{C}$ & $\mathrm{Bp}\left(68^{\circ} \mathrm{C}\right)$ \\
\hline \multicolumn{6}{|l|}{ unit $: \mathrm{g} / 100 \mathrm{~g}$} \\
\hline $\mathrm{C} 16$ & & 5.8 & 5.9 & 5.8 & 5.9 \\
\hline C16: $1 \mathrm{n}-7$ & & 0.1 & 0.1 & 0.1 & 0.1 \\
\hline $\mathrm{C} 18$ & & 2.6 & 2.6 & 2.7 & 2.6 \\
\hline C18: $1 \mathrm{n}-9$ & & 29.9 & 29.7 & 30.4 & 29.4 \\
\hline C18: 2 n-6 & & 55.8 & 56.3 & 55.1 & 56.7 \\
\hline C18: 3 n-3 & & 0.4 & 0.4 & 0.4 & 0.4 \\
\hline $\mathrm{C} 20$ & & 0.2 & 0.2 & 0.2 & 0.2 \\
\hline $\mathrm{C} 22$ & & 1.8 & 1.6 & 1.8 & 1.6 \\
\hline$\Sigma$ SFAs & & 10.4 & 10.3 & 10.5 & 10.3 \\
\hline$\Sigma$ MUFAs & & 35.8 & 35.7 & 36.4 & 35.4 \\
\hline$\Sigma$ PUFAs & & 56.2 & 56.7 & 55.4 & 57.1 \\
\hline Pooled SD & & 0.3 & 0.2 & 0.3 & 0.3 \\
\hline Extraction yield (\%) & & $36.6 \pm 0.6$ & $36.7 \pm 1.0$ & $36.9 \pm 0.4$ & $53.4 \pm 0.4$ \\
\hline
\end{tabular}

caraway essential oil and sunflower oil.

\subsubsection{Qualitative and quantitative comparison of extracts from sunflower seeds}

Extraction yields and fatty acid distribution in sunflower oils obtained with $n$-butane (at $20^{\circ} \mathrm{C}, 30^{\circ} \mathrm{C}$ and $40{ }^{\circ} \mathrm{C}$ ) and $n$-hexane are compared in Table 3. The use of $n$-butane enabled to reach an average oil yield of $36.7 \%$ (Table 3 ). Increasing extraction temperature from $20^{\circ} \mathrm{C}$ to $40^{\circ} \mathrm{C}$ did not impact oil extraction, as observed by (Nimet et al., 2011). The lack of influence of temperature on the extraction yield tends to indicate that in this extraction, the limiting factor is not the internal transport but the mass transfer of oil into the bulk phase. This limitation could be overcome by adding a stirrer to homogenize the mixture and facilitate solvent contacting with the raw material. Extraction performed with $n$-hexane results in higher yields than with $n$-butane (53\%, Table 3 ) probably due to the higher temperature for $n$-hexane extraction $\left(20^{\circ} \mathrm{C}-40^{\circ} \mathrm{C}\right.$ for $n$ butane and $68{ }^{\circ} \mathrm{C}$ for $n$-hexane).

Extracted sunflower oils from both solvents are composed of 55-57 g/100 g of poly-unsaturated fatty acids, 35-36 g/100 g of mono-unsaturated fatty acids and $10 \mathrm{~g} / 100 \mathrm{~g}$ of saturated fatty acids. Fatty acids distributions are similar for both studied solvents. It is also interesting to notice that the temperature range (from $20{ }^{\circ} \mathrm{C}$ for $n$-butane to $68^{\circ} \mathrm{C}$ for $n$-hexane) does not impact on fatty acid distribution, as observed by (Nimet et al., 2011). Sunflower oils can be extracted by $n$-butane with an equal fatty acid composition compared to $n$-hexane, even at low temperatures $\left(20^{\circ} \mathrm{C}\right)$.

\subsubsection{Qualitative and quantitative comparison of extracts from caraway seeds}

Comparison of caraway seeds extract in terms of yield and composition is reported in Table 4. Extraction yield using $n$-butane is dependent on temperature: an increase of $6.5 \%-10.9 \%$ could be noted by increasing extraction temperature from $20^{\circ} \mathrm{C}$ to $40^{\circ} \mathrm{C}$. The highest extraction yield was reached for $n$-hexane $\left(15 \%\right.$ at $\left.68{ }^{\circ} \mathrm{C}\right)$. Caraway seeds contain up to $6 \mathrm{~g} / 100 \mathrm{~g}$ of essential oil and a higher amount of fatty acids (up to $8 \mathrm{~g} / 100 \mathrm{~g}$ ) (Bailer, Aichinger, Hackl, de Hueber, \& Dachler, 2001; Laribi, Kouki, Bettaieb, Mougou, \& Marzouk, 2013). Given the extraction yields obtained, the extract is most probably a mixture of essential oil and fatty acids.

In caraway, the main terpenes in essential oil are carvone and limonene (95 g/100 g of terpenic compounds) (Filly et al., 2015). It could be noted from our results that the proportion of carvone over limonene is quite high (over $70 \mathrm{~g} / 100 \mathrm{~g}$, Table 4). These results have also been obtained by other authors (Laribi et al., 2009; Sedláková, Kocourková, Lojková, \& Kuban, 2003). Authors show that the carvone/limonene ratio varies according to drought (Laribi et al., 2009), to caraway variety (Sedláková et al., 2003), or according to the stage of development of caraway, where carvone seem to be accumulating over limonene at the later stages (Bouwmeester,

Table 4

Extraction yield and the relative abundance of carvone and limonene in each extract. Number of replicates $=3$.

\begin{tabular}{ccccccc}
\hline Solvent & $\mathrm{T}\left({ }^{\circ} \mathrm{C}\right)$ & $\begin{array}{c}\mathrm{P} \\
(\mathrm{kPa})\end{array}$ & Time $(\mathrm{h})$ & Extraction yield $(\%)$ & \multicolumn{2}{c}{$\begin{array}{c}\text { Ratio [carvone] / [limonene] } \\
(\mathrm{g} / 100 \mathrm{~g})\end{array}$} \\
\cline { 6 - 7 } & & & & Carvone & Limonene \\
\hline$n$-butane & 20 & 200 & 2 & $6.5 \pm 0.8$ & $89.4 \pm 4.8$ & $10.6 \pm 2.3$ \\
$n$-butane & 30 & 380 & 2 & $8.4 \pm 0.6$ & $90.7 \pm 2.3$ & $9.3 \pm 1.7$ \\
$n$-butane & 40 & 470 & 2 & $10.9 \pm 0.2$ & $91.8 \pm 3.2$ & $8.2 \pm 1.4$ \\
$n$-hexane & $\mathrm{Bp}$ & atm. & 2 & $15.0 \pm 0.7$ & $70.5 \pm 3.0$ & $29.6 \pm 2.4$ \\
\hline
\end{tabular}

* Concentration ratio 


\section{Table 5}

Extraction yield and composition of carrot oleoresin obtained with $n$-hexane and n-butane. Number of replicates $=3$.

\begin{tabular}{|c|c|c|c|c|c|c|c|c|}
\hline \multirow[b]{2}{*}{ solvent } & \multirow[b]{2}{*}{$\begin{array}{c}\mathrm{T} \\
\left({ }^{\circ} \mathrm{C}\right)\end{array}$} & \multirow[b]{2}{*}{$\begin{array}{c}\mathrm{P} \\
(\mathrm{kPa})\end{array}$} & \multirow[b]{2}{*}{$\begin{array}{l}\text { time } \\
\text { (h) }\end{array}$} & \multirow{2}{*}{$\begin{array}{c}\text { carotenoid yield } \\
\left(\mathrm{mg} 100 \mathrm{~g}^{-1}\right. \\
\text { DM) }\end{array}$} & \multicolumn{4}{|c|}{ HPLC identified carotenoids (g/100 g) } \\
\hline & & & & & $\begin{array}{c}\alpha- \\
\text { carotene }\end{array}$ & $\begin{array}{c}\beta- \\
\text { carotene }\end{array}$ & lutein & lycopene \\
\hline$n$-butane & 20 & 200 & 2 & $14.8 \pm 1.5$ & $35.2 \pm 0.1$ & $64.8 \pm 0.3$ & tr. & tr. \\
\hline$n$-butane & 30 & 380 & 2 & $23.1 \pm 3.8$ & $35.2 \pm 0.1$ & $64.8 \pm 0.2$ & tr. & tr. \\
\hline$n$-butane & 40 & 470 & 2 & $25.7 \pm 3.6$ & $35.2 \pm 0.2$ & $64.8 \pm 0.3$ & tr. & tr. \\
\hline$n$-hexane & 68 & atm. & 1 & $55.8 \pm 7.6$ & $36.0 \pm 1.6$ & $64.0 \pm 1.2$ & tr. & tr. \\
\hline
\end{tabular}

Gershenzon, Konings, \& Croteau, 1998).

As an oxygenated compound, the polarity of carvone is higher than limonene's which is a hydrocarbon. However, extracts using $n-$ butane or $n$-hexane showed a higher proportion of carvone (70.5-91.8 g/100 g) than limonene $(8.2-10.6 \mathrm{~g} / 100 \mathrm{~g})$. For $n$ butane, the proportion of carvone tends to increase with temperature (from 89.4 to $91.8 \mathrm{~g} / 100 \mathrm{~g}$ with increasing temperatures from $20{ }^{\circ} \mathrm{C}$ to $40{ }^{\circ} \mathrm{C}$ ). For $n$-hexane extract, a difference in range of proportions was noticed as a higher amount of limonene was detected (29.6 g/100 g against 8.2-10.6 g/100 g for $n$-butane extracts). Surprisingly, $n$-butane seemed to be more selective towards carvone than $n$-hexane.

\subsubsection{Qualitative and quantitative comparison of extracts from dried carrots}

Comparison of carotenoid yields obtained in liquefied $n$-butane show a positive impact of temperature with an increase from $14.8 \%$ to $25.7 \%$ at $20^{\circ} \mathrm{C}$ and $40{ }^{\circ} \mathrm{C}$ respectively (Table 5). However a higher yield was obtained for the reference in $n$-hexane with $55.8 \%$. This difference can probably be explained by the higher temperature of $n$-hexane extraction.

Extracts composition obtained with both $n$-butane and $n$-hexane were very similar with a proportion of $\alpha$-carotene comprised between 35.2 and $36 \mathrm{~g} / 100 \mathrm{~g}$ respectively and a proportion of $\beta$ carotene comprised between 64.8 and $64 \mathrm{~g} / 100 \mathrm{~g}$ respectively. Those compositions are in accordance with previous results (YaraVaron et al., 2016). Neither lycopene nor lutein were detected in quantifiable amount. This observation can be explained by the low fraction of lutein in carrots carotenoids (1-5 g/100 g) (Amosova, Ivakhnov, Skrebets, Ulyanovskiy, \& Bogolitsyn, 2015) and by the low solubility of lycopene in apolar solvents, due to its relative high polarity. These results suggest an equal carotenoid composition in the raw material and that liquefied $n$-butane allowed extraction of a fraction of it.

Overall, these experimental data show that the developed process with the use $n$-butane is suitable for extraction of lipophilic compounds. Extraction could be achieved even at low temperatures $\left(20^{\circ} \mathrm{C}\right)$ for $n$-butane and with extraction yields increasing with temperatures (up to $40{ }^{\circ} \mathrm{C}$ ). It could also be noticed that an equal extract composition was obtained with $n$-butane compared to $n$-hexane, except for caraway extracts, where a higher proportion of carvone upon limonene was obtained (80-90 g/100 g of carvone for $n$-butane extracts and $70 \mathrm{~g} / 100 \mathrm{~g}$ of carvone for $n$-hexane extract). However, higher mass extraction yields were systematically obtained with $n$-hexane. This gap could be reduced by acting on different process parameters such as temperature and addition of a stirring device to enhance plant material-liquefied gas contacting. Kinetic limitation due to a slow mass transfer has been reported for compressed fluid processes such as supercritical $\mathrm{CO}_{2}$ even if the continuous circulation of $\mathrm{CO}_{2}$ throughout the matrix generates a stirring (Hasan \& Farouk, 2013).

Experimental data and COSMO-RS simulation are well correlated for sunflower oil and carotenoids from carrots. It could be identified that only traces of lutein and lycopene were detected in carrot extracts (obtained with neither $n$-hexane nor $n$-butane), which could be justified by the low amount in our carrot sample. An inverse tendency in experimental data compared to simulation data was identified for carvone. A higher proportion of carvone over limonene was determined in all extracts.

\section{Safety considerations}

Liquefied gas extraction process is simple and can be readily understood in terms of the operating steps to be performed. However, the use of $n$-butane as liquefied gas can pose serious hazards in inexperienced hands (extremely flammable vapors). A high level of safety and attention to details when planning and performing experiments must be used by all the persons. They have to ensure that they seek proper information from knowledgeable sources and that they do not attempt to use this gas unless proper guidance is provided. Only approved equipment in dedicated laboratory or technological hall, with no ignition sources around and proper ventilation (such as ATEX in Europe or HAZLOC in North America), should be used. The same precautions must be taken for $n$-butane storage.

\section{Conclusion}

A new process developed for liquefied gases extraction was evaluated. In terms of application, the process was assessed using $n$-butane for lipophilic natural products extraction. Several technical properties of $n$-butane have been found interesting for extraction processes: chemically inert, easy to evaporate, non-toxic, cheap, commercially available and authorized without limitation for foodstuff production. A COSMO-RS theoretical study confirmed that $n$-butane has a similar solubilization potential to $n$-hexane. The performances of $n$-butane were compared to $n$-hexane for the solid-liquid extraction of three different classes of solutes: aromas, oils and carotenoids. These simulations were confirmed by labscale extractions on caraway seeds, sunflower seeds and carrots. The extraction yields obtained with $n$-butane were lower than $n$ hexane, most probably because of a slow mass transfer inside the solvent due to the lack of stirring. The promising results indicate that $n$-butane can be a non-toxic alternative to $n$-hexane extractions, paving the way to other liquefied gases for extraction.

\section{Acknowledgements}

The authors are grateful to the French organization ANRT ("Association Nationale de la Recherche et de la Technologie") for 
funding this work. They are also grateful to Maria Marco Munoz, director of the Plateforme d'Eco-Extraction de Valréas (PEEV) for having made the ATEX premises available for the experiments with $n$-butane. Finally they want to thank the staff of GREEN research group and Celsius sarl for academic and technical support.

\section{References}

Amosova, A. S., Ivakhnov, A. D. Skrebets, T. E., Ulyanovskiy, N. V., \& Bogolitsyn, K. G. (2015). Supercritical fluid extraction of carotenoids from shantane carrot. Russian Journal of Physical Chemistry B, 8, 963-966.

Bailer, J., Aichinger, T., Hackl, G., de Hueber, K., \& Dachler, M. (2001). Essential oil content and composition in commercially available dill cultivars in comparison to caraway. Industrial Crops and Products, 14, 229-239.

Baysal, T., Ersus, S., \& Starmans, D. A. J. (2000). Supercritical CO2 extraction of $\beta$ carotene and lycopene from tomato paste waste. Journal of Agricultural and Food Chemistry, 48, 5507-5511.

Ben Rahal, N., Barba, F. J., Barth, D., \& Chevalot, I. (2015). Supercritical CO2 extraction of oil, fatty acids and flavonolignans from milk thistle seeds: Evaluation of their antioxidant and cytotoxic activities in Caco-2 cells. Food and Chemical Toxicology, 83, 275-282.

Bouwmeester, H. J., Gershenzon, J., Konings, M. C., \& Croteau, R. (1998). Biosynthesis of the monoterpenes limonene and carvone in the fruit of caraway I. Demonstration of enzyme activities and their changes with development. Plant Physiology, 117, 901-912.

Box, G. E. P., Hunter, W. G., \& Hunter, J. S. (1978). Statistics for experimenters, an introduction to design, data analysis, and model building (p. 352). New York: Wiley and sons.

Brennen, C. E. (1995). Cavitation and bubble dynamics. New York: Oxford University Press.

Chemat, F. (2011). Éco-extraction du végétal: Procédés innovants et solvants alternatifs. Paris: Dunod.

Chemat-Djenni, Z., Ferhat, M. A., Tomao, V., \& Chemat, F. (2010). Carotenoid extraction from tomato using a green solvent resulting from orange processing waste. Journal of Essential Oil Bearing Plants, 13, 139-147.

Chemat, F., \& Vian, M. (2014). Alternative solvents for natural products extraction. Berlin: Springer.

Clará, R. A., Marigliano, A. C. G., \& Sólimo, H. N. (2009). Density, viscosity, and refractive index in the range (283.15 to 353.15 ) $\mathrm{K}$ and vapor pressure of $\alpha$ pinene, $d$-limonene, $( \pm)$-Linalool, and citral over the pressure range $1.0 \mathrm{kPa}$ atmospheric pressure. Journal of Chemical \& Engineering Data, 54, 1087-1090.

Coelho, J. P., Cristino, A. F., Matos, P. G., Rauter, A. P., Nobre, B. P., Mendes, R. L., ... Palavra, A. F. (2012). Extraction of volatile oil from aromatic plants with supercritical carbon dioxide: Experiments and modeling. Molecules, $17,10550-10573$.

Couto, R. M., Simões, P. C., Reis, A., Da Silva, T. L., Martins, V. H., \& Sánchez-Vicente, Y. (2010). Supercritical fluid extraction of lipids from the heterotrophic microalga Crypthecodinium cohnii. Engineering in Life Sciences, 10, 158-164.

Farhat, A., Fabiano-Tixier, A.-S., Maataoui, M. E., Maingonnat, J.-F., Romdhane, M., \& Chemat, F. (2011). Microwave steam diffusion for extraction of essential oil from orange peel: Kinetic data, extract's global yield and mechanism. Food Chemistry, $125,255-261$.

Filly, A., Fabiano-Tixier, A. S., Fernandez, X., \& Chemat, F. (2015). Alternative solvents for extraction of food aromas. Experimental and COSMO-RS study. LWT - Food Science and Technology, 61, 33-40.

Filly, A., Fabiano-Tixier, A.-S., Lemasson, Y., Roy, C., Fernandez, X., \& Chemat, F. (2014). Extraction of aroma compounds in blackcurrant buds by alternative solvents: Theoretical and experimental solubility study. Comptes Rendus Chimie, $17,1268-1275$.

Franc, J.-P., \& Michel, J.-M. (2005). Fundamentals of cavitation. In J.-P. Franc, \& J.M. Michel (Eds.), Vol. 76. Fluid mechanics and its applications (pp. 265-285). London: Kluwer Academic Publishers.

Hasan, N., \& Farouk, B. (2013). Mass transfer enhancement in supercritical fluid extraction by acoustic waves. The Journal of Supercritical Fluids, 80, 60-70.

Hubert, P., \& Vitzthum, O. G. (1978). Fluid extraction of hops, spices, and tobacco with supercritical gases. Angewandte Chemie International Edition in English, 17, $710-715$.

Ishida, B. K., \& Chapman, M. H. (2009). Carotenoid extraction from plants using a novel, environmentally friendly solvent. Journal of Agricultural and Food Chemistry, 57, 1051-1059.

Jesus, A. A., Almeida, L. C., Silva, E. A., Filho, L. C., Egues, S. M. S., Franceschi, E.,... Dariva, C. (2013). Extraction of palm oil using propane, ethano and its mixtures as compressed solvent. The Journal of Supercritical Fluids, 81, $245-253$.

Johnson, L. A., \& Lusas, E. W. (1983). Comparison of alternative solvents for oils extraction. Journal of the American Oil Chemists' Society, 60, 229-242.

Kanda, H., \& Li, P. (2011). Simple extraction method of green crude from natural blue-green microalgae by dimethyl ether. Fuel, 90, 1264-1266.

Kanda, H., \& Makino, H. (2009). Clean up process for oil-polluted materials by using liquefied DME. Journal of Environment and Engineering, 4, 356-361.

Klamt, A. (2003). Prediction of the mutual solubilities of hydrocarbons and water with COSMO-RS. Fluid Phase Equilibria, 206, 223-235.
Koubaa, M., Barba, F. J., Mhemdi, H., Grimi, N., Koubaa, W., \& Vorobiev, E. (2015). Gas assisted mechanical expression (GAME) as a promising technology for oil and phenolic compound recovery from tiger nuts. Innovative Food Science \& Emerging Technologies, 32, 172-180.

Koubaa, M., Mhemdi, H., Barba, F. J., Angelotti, A., Bouaziz, F., Chaabouni, S. E., et al. (2016). Seed oil extraction from red prickly pear using hexane and supercritical CO2: Assessment of phenolic compound composition, antioxidant and antibacterial activities. Journal of the Science of Food and Agriculture. http:// dx.doi.org/10.1002/jsfa.7774 (in press).

Lapkin, A. A., Plucinski, P. K., \& Cutler, M. (2006). Comparative assessment of Technologies for extraction of artemisinin. Journal of Natural Products, 69, 1653-1664.

Laribi, B., Bettaieb, I., Kouki, K., Sahli, A., Mougou, A., \& Marzouk, B. (2009). Water deficit effects on caraway (Carum carvi L.) growth, essential oil and fatty acid composition. Industrial Crops and Products, 30, 372-379.

Laribi, B., Kouki, K., Bettaieb, T., Mougou, A., \& Marzouk, B. (2013). Essential oils and fatty acids composition of tunisian, German and Egyptian caraway (Carum carvi L.) seed ecotypes: A comparative study. Industrial Crops and Products, 41, $312-318$.

Mamidipally, P. K., \& Liu, S. X. (2004). First approach on rice bran oil extraction using limonene. European Journal of Lipid Science and Technology, 106, 122-125.

Mikkelsen, S. H., \& Miljøstyrelsen, D. (2014). Survey of N-hexane: Danish Ministry of the environment. Environmental Protection Agency.

Mustapa, A. N., Manan, Z. A., Mohd Azizi, C. Y., Nik Norulaini, N. A., \& Omar, A. K. M. (2009). Effects of parameters on yield for sub-critical R134a extraction of palm oil. Journal of Food Engineering, 95, 606-616.

Nimet, G., da Silva, E. A., Palú, F., Dariva, C., Freitas, L. d. S., Neto, A. M., et al. (2011). Extraction of sunflower (Heliantus annuus L.) oil with supercritical CO2 and subcritical propane: Experimental and modeling. Chemical Engineering Journal, $168,262-268$.

Novello, Z., Scapinello, J., Magro, J. D., Zin, G., Luccio, M. D., Tres, M. V., et al. (2015). Extraction, chemical characterization and antioxidant activity of andiroba seeds oil obtained from pressurized n-butane. Industrial Crops and Products, 76 697-701.

Oshita, K., Toda, S., Takaoka, M., Kanda, H., Fujimori, T., Matsukawa, K., et al. (2015). Solid fuel production from cattle manure by dewatering using liquefied dimethyl ether. Fuel, 159, 7-14.

Pessoa, A. S., Podestá, R., Block, J. M., Franceschi, E., Dariva, C., \& Lanza, M. (2015). Extraction of pequi (Caryocar coriaceum) pulp oil using subcritical propane: Determination of process yield and fatty acid profile. The Journal of Supercritical Fluids, 101, 95-103.

Sedláková, J., Kocourková, B., Lojková, L., \& Kuban, V. (2003). Determination of essential oil content in caraway (Carum carvi L.) species by means of supercritical fluid extraction. Plant Soil and Environment, 49, 277-282.

Sekhon, J. K., Maness, N. O., \& Jones, C. L. (2015). Effect of preprocessing and compressed propane extraction on quality of cilantro (Coriandrum sativum L.). Food Chemistry, 175, 322-328.

Sicaire, A.-G., Vian, M., Fine, F., Carre, P., Tostain, S., \& Chemat, F. (2015). Experimental approach versus COSMO-RS assisted solvent screening for predicting the solubility of rapeseed oil. OCL, 22, 404.

Sicaire, A.-G., Vian, M., Fine, F., Joffre, F., Carre, P., Tostain, S., et al. (2015). Alternative bio-based solvents for extraction of fat and oils: Solubility prediction, global yield, extraction kinetics, chemical composition and cost of manufacturing. International Journal of Molecular Sciences, 16, 8430-8453.

da Silva, C. M., Zanqui, A. B., Gohara, A. K., de Souza, A. H. P., Cardozo-Filho, L. Visentainer, J. V., ... Matsushita, M. (2015). Compressed n-propane extraction of lipids and bioactive compounds from Perilla (Perilla frutescens). The Journal of Supercritical Fluids, 102, 1-8.

Strati, I. F., \& Oreopoulou, V. (2011). Process optimisation for recovery of carotenoids from tomato waste. Food Chemistry, 129, 747-752.

Suberu, J., Yamin, P., Cornell, R., Sam, A., \& Lapkin, A. (2016). Feasibility of using 2,3,3,3-Tetrafluoropropene (R1234yf) as a solvent for solid-liquid extraction of biopharmaceuticals. ACS Sustainable Chemistry \& Engineering, 4, 2559-2568.

Virot, M., Tomao, V., Ginies, C., \& Chemat, F. (2008). Total lipid extraction of food using $d$-limonene as an alternative to n-hexane. Chromatographia, 68, 311-313.

Xu, L., Zhan, X., Zeng, Z., Chen, R., Li, H., Xie, T., et al. (2011). Recent advances on supercritical fluid extraction of essential oils. African Journal of Pharmacy and Pharmacology, 5(9), 1196-1211.

Yang, C., Teo, K. C., \& Xu, Y. R. (2004). Butane extraction of model organic pollutants from water. Journal of Hazardous Materials, 108, 77-83.

Yara-Varon, E., Fabiano-Tixier, A. S., Balcells, M., Canela-Garayoa, R., Bily, A., \& Chemat, F. (2016). Is it possible to substitute hexane with green solvents for extraction of carotenoids? A theoretical versus experimental solubility study. RSC Advances, 6, 27750-27759.

Zanqui, A. B., de Morais, D. R., da Silva, C. M., Santos, J. M., Gomes, S. T. M., Visentainer, J. V., ... Matsushita, M. (2015). Subcritical extraction of flaxseed oil with n-propane: Composition and purity. Food Chemistry, 188, 452-458.

\section{Web references}

European Parliament. (2009). Regulation (EC) No 1223/2009 of the European Parliament and of the Council of 30 November 2009 on cosmetic products. http://eur-lex.europa.eu/LexUriServ/LexUriServ.do?uri=OJ:L:2009:342:0059: 0209:en:PDF Accessed 27.09.16. 
Version définitive du manuscrit publiée dans / Final version of the manuscript published in :

LWT - Food Science and Technology (2016), 10 p., DOI: 10.1016/lwt.2016.10.003

Journal homepage : http://www.elsevier.com/locate/lwt

European Parliament. (2009). Directive 2009/32/EC of the European Parliament and of the Council of 23 April 2009 on the approximation of the laws of the Member States on extraction solvents used in the production of foodstuffs and food ingredients. http://eur-lex.europa.eu/legal-content/EN/TXT/PDF/?uri=CELEX: 32009L0032\&from=EN Accessed 27.09.16.

European Parliament. (1997). Directive 97/23/EC of the European Parliament and of the Council of 29 May 1997 on the approximation of the laws of the member states concerning pressure equipment. http://eur-lex.europa.eu/legal-content/ EN/TXT/PDF/?uri=CELEX:31997L0023\&from=en Accessed 27.09.16.

European Parliament. (2014). Directive 2014/34/EU of the European Parliament and of the Council of 26 February 2014 on the harmonisation of the laws of the Member States relating to equipment and protective systems intended for use in potentially explosive atmospheres. http://eur-lex.europa.eu/legal-content/ EN/TXT/PDF/?uri=CELEX:32014L0034\&from=EN Accessed 27.09.16. 